\title{
Focus on Form: Research and its application
}

\author{
Jessica Williams \\ University of Illinois at Chicago
}

Vários estudos experimentais e em sala de aula sugerem que o Foco na Forma (FonF) pode facilitar o desenvolvimento da interlíngua para que se atinja precisão na língua alvo. Porém, uma vasta gama de definições, técnicas e termos similares, às vezes, torna difícil determinar realmente o que significa o termo FonF. Este artigo explora, em detalhes, possíveis interpretações dos termos foco e forma. Além disso, revisita a taxonomia apresentada em Doughty e Williams (1998) para analisar cuidadosamente alguns dos ítens chaves que têm sido sugeridos para atividades de FonF, por exemplo:

- planejamento,

- aproximação da língua alvo,

- interrupção do processo,

- processos cognitivos.

Finalmente, há uma consideração sobre como o efeito do FonF pode variar, dependendo de quando ele acontece durante o desenvolvimento da interlingua.

Focus on Form (FonF), a term first coined by Long $(1988,1991)$ to describe a brief, often instructional, focus on linguistic features embedded in meaningful communication, seems to have struck a chord among many second language teachers ${ }^{1}$. Perhaps this is a result of the inevitable swing of the pendulum: In the heyday and aftermath of Krashen's influence, many researchers and teachers were perhaps closet doubters of the strongest versions of communicative language teaching and now see FonF as permission to reintroduce grammar into their classrooms, where it had long been taboo or else introduced surreptitiously. Of course, many teachers had never really abandoned some formal focus in their classes. Perhaps because of its popularity, there is some confusion with regard to

\footnotetext{
'An earlier version of this paper was given at the Nessa Wolfson Memorial Lecture, April, 2000, at the University of Pennsylvania. Wolfson was a Professor of Educational Linguistics at the University of Pennsylvania until her death from breast cancer in 1990. Her husband, Harvey Wolfson, established an annual lecture series in her honor. This lecture was the ninth in the series.
} 
various competing terms, such as focus on formS and the closely related form-focused instruction, which is not synonymous with FonF. Spada (1997) uses form-focused instruction as an umbrella term for all approaches, including FonF, that draw learner attention to formal aspects of language. In principal, this could include a decontextualized, highly metalinguistic, teacher-centered grammar lesson, which, of course, is antithetical to FonF. This article is an attempt to clarify what I mean by FonF and to explore some of the important features of such an approach.

Long and Robinson operationalize FonF in terms of the allocation of the learner's focal attention. Their deliberately narrow definition requires a problem-oriented trigger. This means that the focus of attention on a particular item is brought about by a breakdown of some sort, some problem in either production or comprehension. This pretty much limits teachers to waiting for issues to emerge and responding to them as needed. Doughty and Williams (1998a) offer approaches which are broader, allowing for a planned, and even separated, instructional focus on form that need not necessarily involve a problem-trigger. However, Doughty and Williams (1998b) clearly imply that an optimal FonF technique would be one in which meaning and form are processed simultaneously. Given the strict definition offered by Long and Robinson, and the increasingly loose ones being offered in the literature, it is important to specify exactly what is meant by FonF.

The term Focus on Form consists of two important parts, the focus and the form. In my own view, the first $F$ is the heart of the term because it gets at issues of cognitive engagement and learning processes. In Doughty and Williams (1998b), focus is taken to mean any brief turning or dividing of learner attention from an act of communication, such as reading, conversing, listening etc., toward some feature of language. In most studies, form is assumed to be a structural feature, though, in fact, it need not be limited to these kinds of items and can be viewed more broadly. For instance, it could also be lexical, as in the use of a typographic enhancement or glossing in a reading, to heighten learner attention to a word's meaning, not just its structural features. FonF could equally involve the drawing of learner attention to a second language pragmatic convention, for instance, the use of certain kinds of hedges to mark or reinforce social relationships (Bardovi-Harlig and Dörnyei, 1998; Celce Murcia, Dörnyei, and Thurrel, 1997) or to indicate lack of commitment in academic writing (e.g., Hyland, 1996). 
The crucial thing to remember in FonF is that although there is a brief or simultaneous focus on code features: pronunciation, inflectional morphology, word form, word definition etc., the overriding focus is on the processing of meaning in an act of communication. This may be the case even if the instructional focus is separated in time from that communicative act. Doughty (in press) discusses various possibilities for combining the processing of form and meaning. A potential exception to the simultaneous processing ideal is the use of advance planning. Mehnert (1998), Ortega (1999) and Foster and Skehan (1999) all report ways in which opportunities to plan production allow learners to focus on form spontaneously and increase accuracy, as well as try out more complex forms at the forward edge of their ILs. This planning obviously takes place prior to the actual communication, but can still remain part of a FonF approach.

\section{Some important features of $\mathbb{F}$ on $\mathbb{F}$}

There are a variety of techniques and activities that have been suggested to promote FonF, many of which have been discussed in the literature. Because of the diversity of these ideas, it is useful to situate them within some sort of taxonomy. Although it seems evident that, as a package, FonF is worth pursuing, it is not always clear what aspects of the various activities and techniques make them effective, or more likely, sometimes effective and sometimes not. A taxonomy can help in some cases to isolate the features of the various instructional techniques, analyze them separately, and ultimately, manipulate them for more effective instruction. Doughty and Williams (1998b) made a first attempt at this. I will reconsider and reevaluate several of these features, shown here in Figure 1.

- proactive $\leftrightarrow$ reactive

- targeted $\leftrightarrow$ general

- obtrusive $\leftrightarrow$ unobtrusive (interrupts processing)

- teacher $\leftrightarrow$ learner responsibility

Figure 1. Some features in FonF for reconsideration

Doughty and Williams offer proactive versus reactive as a fundamental distinction. However basic, this distinction may be too broad and is subject to misinterpretation. First, it is probably best to consider it a continuum. Second, it is not simply a matter of planning. It is probably a composite of at 
least two specific features. In particular, it is important to distinguish between overall planning, which one hopes all good teachers do, and the specific features of FonF, namely, (a) whether a technique or approach is proactive or reactive, and (b) the degree to which an approach or technique has a specific instructional target. For instance, recasting is clearly a reactive technique, yet the decision to recast, as well as the target of the recasting may well be planned in advance. Alternatively, a general proactive focus on accuracy might be built into an activity in advance, as in the use of increased learner planning time, and instruction to attend to accuracy, without targeting any particular form. Finally, it is possible to have a proactive and specifically targeted activity, such as one in which the form is task-useful (e.g., Day and Shapson, 1991; Spada and Lightbown, 1999). Thus, the proactive-reactive continuum is related to, but separate from, the targeted-general continuum. Figure 2 illustrates this idea graphically. Just one example for each quadrant is included, but there are many other possibilities.

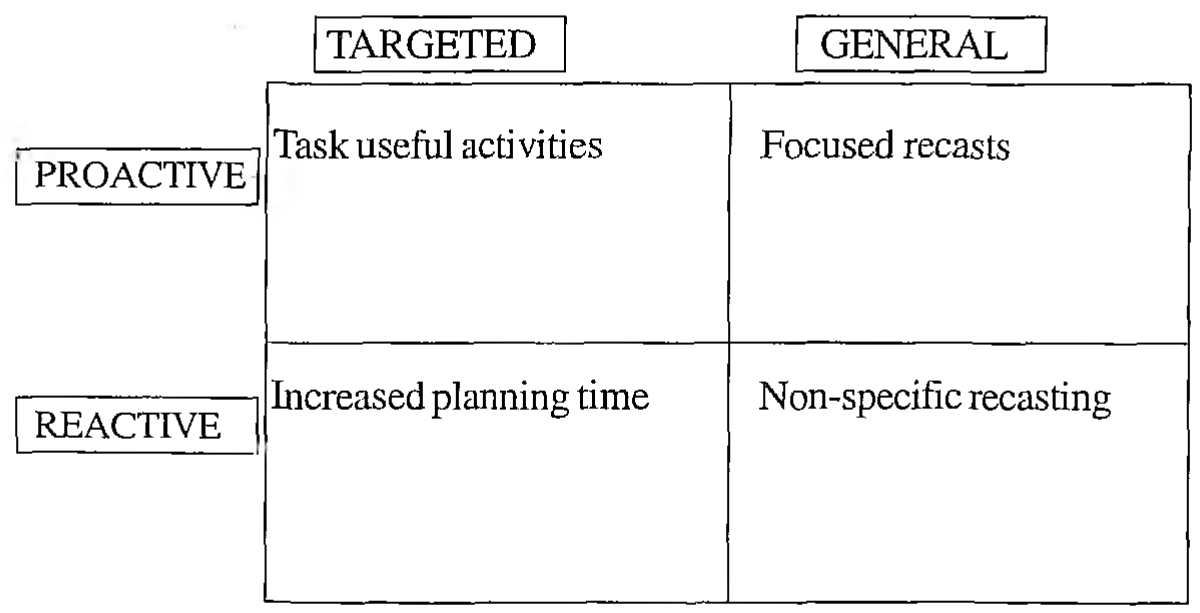

Figure 2. Two related FontF features

A second basic feature discussed in Doughty and Williams is obtrusiveness. Both the proactive-reactive and targetedness continua interact with a continuum of obtrusiveness. The teacher can plan in advance what she hopes her students will focus on. In Doughty and Williams, obtrusiveness simply refers to the degree to which an activity or technique interrupts the flow of communication. A more crucial issue for acquisition, perhaps, is whether it interrupts the processing of meaning. This is a cognitive rather 
than communicative perspective. Whether this interruption of processing is even possible and if so, if it inhibits second language learning is not yet clear. De Bot (2000) argues that processing, and in particular, retrieval, cannot be interrupted. However, many pedagogical techniques appear to be predicated on the assumption that some interruption is required to actively direct learners' attention to the form in question, or to engage learners in the deeper processing some claim is necessary for transfer to long-term memory storage (see Ellis, 1999, for discussion). Similarly, we do not know whether simultaneous processing of form and meaning is possible (see Doughty, in press, for relevant research on this topic from the psychology literature).

In part, any determination regarding these debates will depend on whether awareness is considered a requirement for the conversion of input to intake, a question that remains controversial. If higher levels of awareness are required, this could limit the possibilities for simultaneous processing of form and meaning. VanPatten (1996) has long maintained that the simultaneous processing of form and meaning is unlikely, at least in the initial stages of acquisition. There is preliminary evidence that even supposedly unobtrusive interventions can result in a diminution of performance in the processing of meaning, even as the enhancement may increase noticing. Overstreet (1998), for instance, reports lower comprehension scores for texts with multiple kinds of typographic enhancement than for unenhanced texts.

On the other hand, it has been argued that greater awareness allows for more elaborate forms of learning (see Rosa and O'Neill, 1999; Schmidt, 1995, for discussion) and a variety of experimental studies have suggested an advantage for explicit instruction for the noticing and/or learning of at least some rules or structures (e.g., Carroll and Swain, 1993; DeKeyser, 1995; Ellis, 1993; Kupferberg and Olshtain, 1996; Robinson, 1996, 1997; Rosa and O'Neill, 1999; Spada and Lightbown, 1993, 1999; L. White, 1991). Ellis (1998) refers to all of these pedagogical options as explicit instruction and they would generally be considered obtrusive. Depending on whether this instruction is embedded in some form of communication or the length of this diversion from more meaning-focused activities, they may not even qualify as FonF (see Lightbown, 1998). For instance, although they are included on the Fon F continuum in Doughty and Williams, there is some question as to whether the consciousness raising tasks in studies by Fotos $(1993,1994)$ and Fotos and Ellis (1991) should actually be called FonF at all. These tasks have as their content focus the grammatical rule itself. Thus, although the learners are indeed interacting, they are simply communicating about grammar. This is an important feature that differentiates these tasks from say, the collaborative 
writing tasks used by Swain and her colleagues (1998, Swain and Lapkin, 1995). In these tasks, too, the interaction may focus on formal features of the language, but the discussion is in service of a wider communicative purpose.

A less obtrusive, yet proactive candidate is to expose learners to a new form (for which they are developmentally ready), or to a TL alternative to an $\mathbb{L}$ form in input, with the form highlighted or flagged in some way, what Ellis calls structured input (1998). De Bot (2000) suggests that forlearning to be facilitated, instructional tasks must make TL candidates in the input more attractive for selection than non-TL candidates. Various forms of typographic and other textual enhancement (e.g., flooding) of written input have been discussed at length in the literature (e.g., Jourdenais, Ota, Stauffer, Boyson, and Doughty, 1995; Leow, 1997; J. White, 1998). A structured input approach can also be used in combination with more explicit instruction, as in the processing instruction procedures of VanPatten (1996), in which learners are exposed to floods of relevant problematic structures and also explicitly instructed as to how the structures should be processed, or with other implicit techniques (e.g., Lightbown and Spada, 1999; Williams and Evans, 1998). So far, then FonF activities have been described in terms of three continua: proactive-reactive, targetedness, and obtrusiveness. However, consideration of these three features neglects one crucial element in the learning process: who is doing the planning, reacting, targeting and interrupting. For the most part, the three continua described so far refer to the role of the teacher. Since only the leaner can do the learning, it seems appropriate to focus more on the role of the learner. In Doughty and Williams, this aspect of FonF was described in either/or terms: Is the learner's attention drawn (implicitly) or directed (more forcefully and directly)? Does the learner or teacher manipulate the forms? Both of these essentially point to the locus of responsibility: Is it the teacher/materials or the learner who takes responsibility for initiating the cognitive processes involved in acquisition? (always keeping in mind, of course, that ultimately it is always up to the learner).

Again, there is a wide range, but we can think of three points on a continuum. First, there are traditional activities, in which the teacher or materials take primary responsibility for focusing on formS. Those techniques, in which the teacher controls the process, such as the provision of explicit explanations, and present-and-practice activities, also tend to be the most obtrusive; indeed, most could not be considered FonF. Thus, the extreme end-teacher responsible-overlaps with a high level of obtrusiveness, that is, such activities tend to interrupt the processing of meaning. 
A second, intermediate position would include those techniques that, though still teacher/materials-directed, place more responsibility with the learner in that they provide learners with a guided opportunity to engage in some cognitive process that are said to facilitate acquisition of a targeted form. This would include, for instance, those techniques and activities that encourage learners to notice the gap, that is, to see that their $\Pi$ falls short of the target. Some examples of these would be the use of recasting and again, various structured input activities. Another possibility is that cognitive processes might be triggered by learners' simply not knowing, but needing, the TL form, resulting in their noticing a so-called hole in their IL. This is particularly evident in dialogic activities, as reported in Swain's work (Swain, 1998; in press; Swain and Lapkin, 1998).

\section{Task features and Focus on Form}

Most of the activities described here would be targeted at the noticing/ use of a specific form. There is also the possibility that learners might be given the opportunity to increase focus on form in an activity that does not target specific forms. One promising possibility already mentioned is advanced planning. A widely held assumption is that the human mind is a limited capacity processor. VanPatten (1996) has argued that learners have a natural tendency to process meaning before form. One way of allowing learners to manage the cognitive load of both types of processing simultaneously is to allow them more time and attention to plan their production. Specifically, Mehnert (1998) found that, with even a minute of planning time, accuracy increased significantly on an exposition task, with a longer period needed for an instructional task. Some research has shown that the effect of planning extends beyond increasing formal accuracy. Increased pre-task planning time may also affect fluency and complexity, depending on the task, the amount of time and the proficiency of the learners. Ortega proposes that "an increased focus on form during pretask planning ...(provides) the space for the learner to devote conscious attention to formal and systematic aspects of the language needed for a particular task" (1999:120). She notes that, in many studies, it is not clear whether planning time results in planning of actual language use or whether it eases the cognitive load by allowing learners to manage more global task demands initially, freeing up attention to devote to accuracy during execution of the task. In her own study of the effect of planning time, she included retrospective interviews and found that, in fact, learners do both, often planning at the sentence level. However, she found no significant effect 
for planning time on accuracy in a story retell task. Overall, the results for effect of planning time on accuracy are mixed and difficult to compare because they involve different tasks, planning conditions and proficiency levels. However, Ortega notes that there is enough evidence of increased focus on form with additional planning time to make it a promising avenue for further research. Beyond planning time, one can speak more broadly of the manipulation of task features, which can help free up learners' attention so that they can focus on form independently and as needed. Skehan (1996) suggests, for instance, that if task familiarity or complexity are decreased, learners may be more able to focus on accuracy. In fact, however, Skehan and Foster (1999) found that fluency was more likely to be influenced by the predictability of a task than accuracy. In another recent study, Gass, Mackey, Alvarez-Torres and Fernandez-García (1999) examined the effect of task repetition on accuracy, with the underlying assumption that, with the increased content familiarity which accompanied the repeated task, more attention might be available to improve accuracy. They found some modest support for this, though they found that improvements did not carry over to new tasks. Izumi, Bigelow, Fujiwara and Fearnow (1999) report similar effects for task repetition, in this case, on noticing. This manipulation of task features may prove a useful pedagogical tool, particularly for non-targeted proactive FonF, one which is both unobtrusive and places a large degree of the responsibility on the learner.

\section{Noticing the gap/moticing the holle and stages of $1 \mathrm{~L}$ acquisition}

Two types of activities that are often suggested as facilitative of second language learning are notice-the-gap and notice-the-hole activities. In the discussion above, they were considered together. Indeed, they appear to be related phenomena (Swain, 1995; 1998), but they differ in crucial ways that point to another area of needed research in FonF. Noticing the gap occurs when learners notice that their IL differs from the target. This is another way of saying that they figure out that they are making an error; perhaps that they are using a stabilized IL form. It necessarily involves noticing both the $\mathrm{IL}$ and TL forms, presumably input and output forms. The second, noticing the hole, takes place at the point at which learners realize that they do not have the means to say something that they want to say. This differs from noticing the gap, in that learners may nothave yet developed an IL form to express what they want. Activities that promote noticing the hole seek to intervene at the point at which input become intake. There is no particular implication 
that the hole will be filled by a TL form. In contrast, activities that facilitate noticing the gap attempt to destabilize the $\mathrm{IL}$ and move it toward more target-like accuracy, with a combination of positive and negative evidence. By definition, noticing the gap suggests an $\mathbb{L}$ form to which the TL form can be compared. Learners may believe they already know the word or form and they must now notice that they do not, at least not exactly or completely. In sum, in the ideal world, holes get filled and gaps get closed. Figure 3 is an attempt to illustrate this idea.

\section{Noticing the hole}
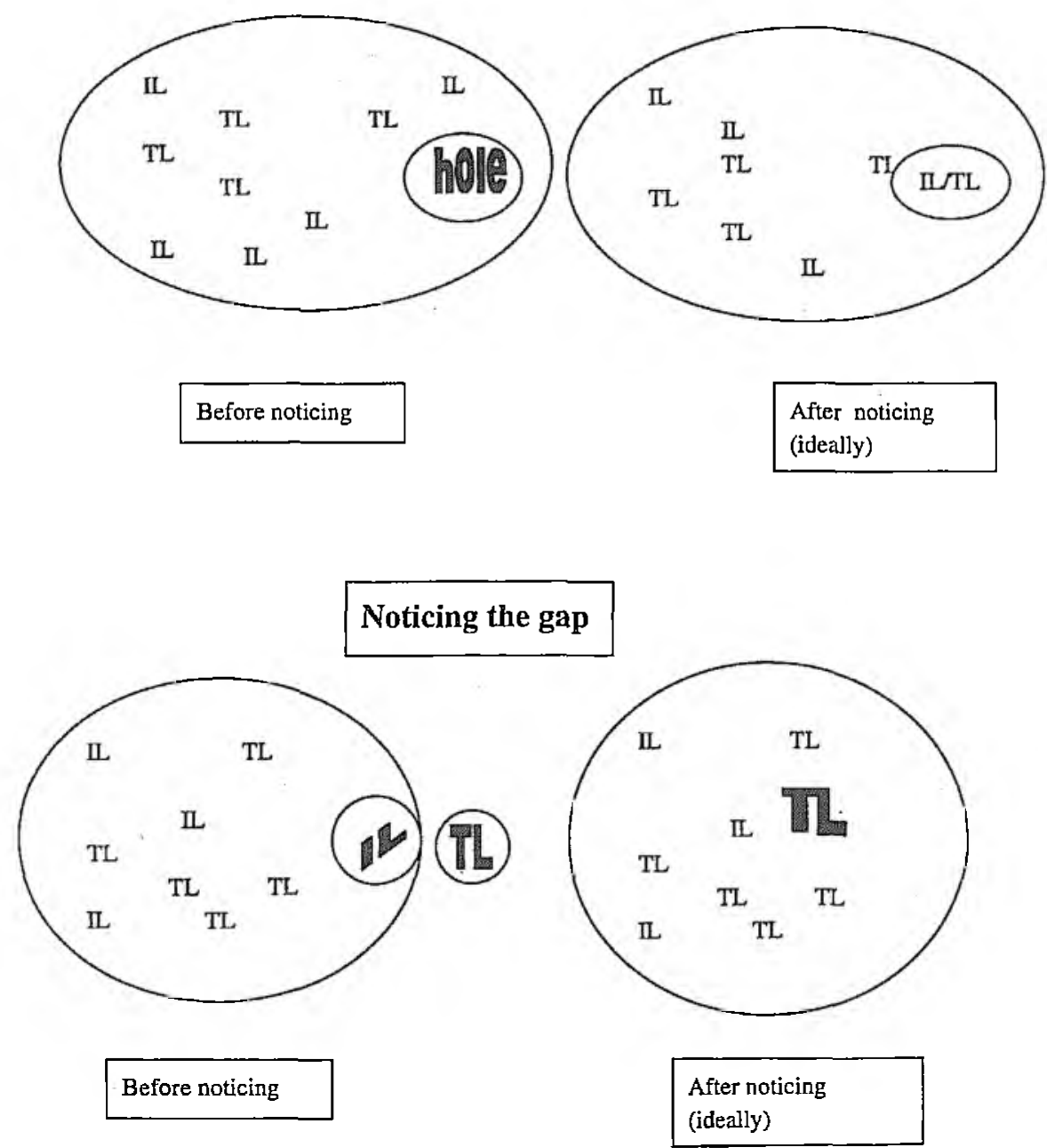

Figure 3. Noticing the hole and noticing the gap 
It is important to be precise about this issue. Many techniques involving explicit instruction and structured input are attempts to modify $\mathbb{L}$ in the early stages of acquisition. In other words, they are attempts to impact the course of acquisition at the initial point of intake, either to ensure that input becomes intake, or that intake is target-like by structuring input appropriately. This is one of the central claims of VanPatten's input processing: that this is the only point at which classroom activities can have an impact on the developing $\Pi$. He argues that output practice only impacts control; it can speed up access to IL forms, increasing fluency, but will have no effect on the developing system. Only input during the process of comprehending meaning can do that. It is, of course, possible for these activities take place prior to the learner developing any $\mathrm{IL}$ form and this seems to be the intention, based on VanPatten's model (1996). However, it seems likely that much of the input processing work in real classrooms occurs when learners have already developed somewhat stabilized $\mathrm{IL}$ forms, which the teacher hopes can be destabilized though this processing practice.

The point is that very little work has explicitly addressed the need to differentiate the effect of FonF at various points of IL development, although some have examined the differential effect of drawing/attracting attention to form at different levels of proficiency or developmental readiness (Mackey, 1999; Mackey and Philp, 1998; Nassaji and Swain, in press; Spada and Lightbown, 1999). One stage of acquisition that has been the subject of much research is noticing. Several studies have attempted to measure noticing or in some cases, simply memory, assuming that this is the first step on the way to acquisition. In other words, do learners remember a word or form from a previous activity, text etc.? As yet, though, we do not have a clear idea of how directly this relates to their acquisition. One study of interest, again, is Izumi et al. (1999), who note that their FonF activity had a facilitating effect on noticing, but apparently not on acquisition, as measured by grammaticality judgment and production tests. They attribute this result to the heavy cognitive demand of the experimental tasks and suggest that the forms that were noticed may not have made it beyond short term memory. This is an important factor to consider in designing FonF activities since the ultimate goal is long-term storage.

In terms of Gass's model of SLA (1997), notice-the-hole activities might engage learning processes at the point of apperception or, somewhat later, at intake. The difference between noticing the hole and noticing the gap may be crucial in terms of these storage requirements and the cognitive 
processes involved. Noticing the gap required cognitive comparison. This means incoming input would have to be compared either to representations stored in long-term memory or to traces left in short-term memory. Precisely how this works is not clear (though see Doughty, in press). De Bot (2000), for instance, maintains that direct comparison is unlikely, in that incoming input is always processed before it is stored and any comparison to it can be made. Noticing the hole, on the other hand, would seem to be a simpler process in that it does not require comparison to representations that have been previously stored (except possibly L1 representations).

Opportunities for noticing the hole occur in activities in which learners feel the need to use a form that they lack, presumably a task-useful or, better still, the ever-elusive task-essential activity (Loschky and Bley-Vroman, 1993). Possibilities for this can be found in a number of studies (e.g., Day and Shapson, 1991, Harley, 1998; Loschky and Bley-Vroman, 1993). Another familiar example is Swain's use of the dictogloss or other types of text recreation (1998, in press). The important difference between some of these activities and those using structured input is that the noticing process is triggered by an output activity. Learners are asked to reconstruct a passage that is fairly easily understood. However, actually recreating it requires that they do so with a good deal of precision. The need to do this prompts them to focus on forms they may not have in their IL.

Izumi, et al. (1999), describe an interesting variation on this method of using output to encourage noticing the gap or hole. In their study, learners were also required to reconstruct a text, but had a subsequent opportunity to study relevant input. The intention here was to focus the learners' attention more narrowly on the subsequent input that they would need for the next output task. In contrast, in Swain's tasks, learners consulted one another in dialogic reconstructions of meaning, but had no recourse to the original input, thus allowing for the possibility that the target forms would be reconstructed incorrectly. Indeed this did happen, though rarely. In the Izumi et al. (1999) study, learners were allowed to recheck their hypotheses against the target before reattempting output.

\section{A broader view of form}

Up to this point, the discussion has considered form in terms of morphosyntactic structure. However, this is not the only possibility. Here we return to the second F in FonF: form. Long (1996) offers an example of using FonF to call attention to problematic words. This flagging of lexical 
items and in particular, their meaning, rather than a grammatical form, is a broader view of FonF in that, instead of processing form along with meaning, the learner is processing word meaning in the context of comprehending spoken or written text. Still, it falls within a general discussion of simultaneous or dual processing, which is at the heart of FonF.

An example of this can be found in an ongoing study which tries to apply some of these ideas to lexical acquisition, in a treatment that combines the possibilities of structured input, noticing the hole, and subsequent access to input (Rott, Williams and Cameron, 2000). One of the goals of the study is to test the effect of one type of glossing as a FonF technique. Glosses have long been used in an effort to improve reading comprehension and to foster lexical development (Davis, 1989; Holly and King, 1971; Hulstijn, 1992; Hulstijn, et al., 1996; Jacobs, 1994; Jacobs, Dufon and Fong, 1994; Ko, 1995; Watabe, 1997). Marginal glosses allow learners to attend to the meaning of a new word without diverting all attention from the task of reading. Rott, et al., includes two interventions with an aim of getting learners to attend more closely to word meaning. The first intervention is the use of a multiple choice marginal glosses. Multiple choice glosses rather than straight Ll definitions were used, based on work by Hulstijn (1992). He suggested that providing multiple choice glosses is superior to simply giving word meanings because it requires greater effort on the learners' part and therefore, it is hoped, leads to deeper processing. Deeper processing is associated with greater retention. The second intervention involves input-output cycles. The text is divided into four sections and, after each section, learners are asked to reconstruct that section of the text in the L2. Results suggest that lexical acquisition is highest when learners are provided with glosses and when they are required to engage in these repeated input-output cycles. The idea behind the design is that the interventions provide both the opportunity to notice the hole and the means to fill the hole. In other words, learners, in the process of reconstructing text in the L2, may realize that they do not have the required word in their lexicon, and subsequently return to the input, primed to focus on the word meaning. In still another twist, in their study of the effect of task repetition, Gass et al. (1999) examine the possibility that, during the execution of a task with familiar content and structure, learners might have more opportunity to recheck, not the input, but their own L2 resources and consequently, modify their output in the direction of the target. This is an interesting example because it cannot really be described as noticing the hole since the participants use some IL form even in the first iteration of the task. Neither can it be accurately described as noticing the gap, since the learners 
are not comparing their output to the TL. Instead, they are comparing their IL production to an aspect of their IL knowledge that they do not yet fully control but can access when they devote more attention to the retrieving it.

\section{Negotiation and feedlback}

There are also other, familiar ways of in which learners are encouraged to notice the gap. Perhaps the two most familiar are (1) implicitly, in the breakdown in communication followed by negotiation and (2) more directly, through feedback on error, which may take a variety of forms. Where do these fit into the arsenal of FonF techniques? Negotiation has traditionally been understood as resulting from problems of message comprehensibility, that is, when interlocutors restructure their utterances in an effort to understand or to be understood (e.g., Ellis, 1999; Mackey,1999; Oliver, 1995, 2000; Pellettieri, 2000; Pica, 1994, 1997; Pica et al., 1996; Shehadeh, 1999; Van den Branden, 1997). Gass and Varonis (1991) distinguish among several types of problems with message comprehensibility, only some of which result in negotiation. Only what they call incomplete understanding is likely to lead to negotiation because it is only in these circumstances that a problem in comprehensibility is recognized. This incorporates the problematicity that is central to Long and Robinson's original definition of FonF. Pica most clearly delineates that ways in which negotiation can focus learner attention on aspects of language: by making target input more noticeable and by providing feedback on output, and in the process, calling attention to discrepancies between the IL and the TL. What is not clear, however, is exactly what the cognitiveconsequences of breakdown followed by negotiation might be. To what degree does it constitute an interruption in the processing of meaning? One the one hand, the main virtue of negotiation, it is said, is that it can offer a simultaneous focus on form and meaning, thus stressing the formmeaningconnection. On the other hand, a breakdown does imply some sort of interruption of communication and therefore, perhaps, also of processing. Again, it is not clear whether and how this interruption provides a favorable condition for acquisition.

Pica (1997) and others (Foster, 1998; Williams, 1999) note, that teachers cannot expect negotiation to occur spontaneously with any frequency; they can only include opportunities that encourage it. Nor can transfer of information tasks guarantee that learners will negotiate (Foster, 1998). With reference to the FonF continua already described, the advantages conferred by the interactional modifications resulting from negotiation would presumably 
be a rather broad. It would be difficult to do any targeted instruction in this way, at least with the tools we have now. There is ample evidence in the literature on interaction that the locus of negotiation is most often the lexicon and not morphosyntactic features. Pica (1997) notes, however, that the fact that learners rarely negotiate morphosyntactic and other less salient features is not because it is not possible to do so, but because the kinds of activities typical of communicative classrooms rarely require them to. This would be an interesting avenue to pursue: to get learners to focus their negotiations on a wider variety of predetermined features. One interesting recent example is preliminary study of negotiation in network-based communication, in which Pellettieri (2000) finds significant differences across tasks in the amount of negotiation surrounding morphosyntactic forms.

Lyster (1998; Lyster and Ranta 1997) has distinguished between the negotiation of meaning just described, and the negotiation of form, which has the more pedagogical purpose of increasing accuracy and precision of message form, and is usually initiated by the teacher. In this case, message comprehensibility is not usually at issue; it is essentially various forms of feedback on error in message form. There is a continuing controversy over the effectiveness of this technique, since it is not always certain that what the teacher (or other interlocutor) points out as an error will actually be noticed as an error or, even if this happens, that the learner will be able to do anything about it. Lyster and Ranta distinguish among various types of feedback, and indeed there has been a proliferation in the literature of terms for this. Muranoi (to appear) uses the term interaction enhancement to describe a pedagogical technique that interweaves input and output enhancement. In response to TL use, the teacher repeats learner output, helping to confirm their hypotheses. In response to nonTL output, the teacher requests repetition, and if necessary, recasts learner output. Muranoi found this technique to be effective in increasing accuracy in article use. Similar results can be found in Noboyushi and Ellis (1993) and Takashima and Ellis (1999).

Recasts, that is, modifications of learner output toward the target by an interlocutor/teacher, have been found to be an effective method of providing focused feedback on errors in form, both in experimental (Mackey and Philp, 1998; Long, Inagaki and Ortega, 1998) and classroom studies (Doughty and Varela, 1998). However, Lyster (1998) argues that only those forms of feedback that push learners to use their own resources in reformulating output are effective in destabilizing $I L$, and thus he discounts the value of recasts as an classroom technique. He claims that learners may not know that their nontarget-like output is being corrected, making it difficult for them to detect 
any changes made in the teacher's recast (see also Seedhouse, 1997). It is possible that Lyster found little effect for recasts in his classroom study because the recasts were neither focused nor narrow. Teachers in his study were not systematic in the target of their correction, in contrast to the Doughty and Varela study, in which the teacher targeted just two forms on which to provide feedback. In addition, in their study, the errors were always recast in the same way, by rising intonation to signal the error, followed by a target-like recast of the error if the learner could not provide the TL form. Unlike Lyster, they found a significant effect for recasting on the accuracy of the forms in focus. The recasts in Lyster's study might be characterized as reactive and untargeted, those in Doughty and Varela's study, as reactive and targeted, perhaps suggesting some prominence for the targetedness feature.

There is, of course, a voluminous literature on the effect of error correction more generally, beyond the narrow considerations of recasting. There are continuing heated arguments on the subject and while beyond the scope of this article, there appears to be an ever-growing body of evidence from studies in and out of the classroom that suggests that negative feedback of various kinds can help learners to notice the gap between their own production and the target (e.g., Noboyushi and Ellis, 1993; Oliver, 1995, 2000; Pica et al., 1989, Pica et al, 1996, Takashima and Ellis, 1999; Van den Branden, 1997).

\section{Conclusion}

In summary then, a major role for FonF appears to be in the area of noticing, (1) of a form/word for the first time in the input, potentially leading to a conversion to intake or (2) of the fact that an IL form is at odds with the input, leading to destabilization of that form. Perhaps theseare two points at which FonF activities would be the most useful. In addition, in our

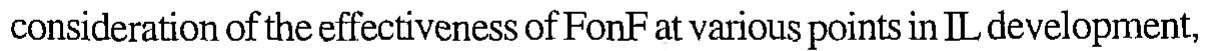
there is the possibility of FonF activities' increasing learner control over IL knowledge, that is, the speed and efficiency with which learners can access their knowledge, might be increased with the use of FonF activities. This possibility is discussed in a recent article by Gass et al. (1999), specifically regarding the use of task repetition to free up learner attention. Indeed, any of the possibilities already mentioned that involve manipulation of task features to adjust attention levels would also be relevant here. Thus, it is at least theoretically possible to find suitable activities to facilitate language acquisition 
and increasing control at many stages of development. Along with all the supportive evidence, however, there is enough counter-evidence, both experimental and anecdotal to warrant continuingcareful and skeptical consideration of the effect of FonF. Some suggest that FonF is more useful in later stages of development (VanPatten, 1996; Williams, 1999) because in the early stages, learners concentrate almost entirely on decoding and expressing meaning. However, further critical discussion of the effectiveness of FonF even at later stages is also indicated, specifically, on the destabilization of $\Pi L$ forms that have been used by the learner for a extended period of time. Obviously, sometimes FonF works; sometimes it does not. The more we know about the factors involved in the activities described here and about the cognitive processes they engage, the more likely we will be to find the reasons for the variable results for FonF reported in the literature, knowledge that can be turned to increasing pedagogical effectiveness.

\section{References}

JENSEN, J.B. A investigação de formas de tratamento e a telenovela: a escalada, parte 1. Revista Brasileira de Lingüística, Petrópolis, v.4, n.2, p.43-73, 1977.

FREEMAN, D. Redefining the relationship between research and what teachers know. In: BAILEY, K.M., NUNAN, D. (Ed.). Voices from the language classroom. Cambridge: Cambridge University Press, 1996. p.88115.

BARDOVI-HARLIG, K.; DÖRNYEI, Z. Do learners recognize pragmatic violations? TESOL Quarterly, Bloomington, v.32, n.2, p. 233262, 1998.

CARROLL, S.; SWAIN, M. Explicit and implicit negative feedback: An empirical study of the learning of linguistic generalizations. Studies in Second Language Acquisition, v.15, p. 357-86, 1993.

CELCE-MURCIA, M.; DÖRNYEI, Z.; THURRELL, S. Direct approaches in $\mathrm{L} 2$ instruction: A turning point in communicative language teaching? TESOL Quarterly, Bloomington, v.31, n. 1, p. 141-152, 1997. DAVIS, J. Facilitating effects of marginal glosses on foreign language reading. Modern Language Joumal, v. 73, p. 41-48, 1989.

DAY, E.; SHAPSON, S. Integrating formal and functional approaches in language teaching in French immersion: An experimental study. Language Learning, v. 41, p. 25-58, 1991. 
DE BOT, K. Psycholinguistics in applied linguistics: Trends and perspectives. Annual Review of Applied Linguistics, v. 20, p. 224-237, 2000. DEKEYSER, R. Learning second language grammar rules: An experiment with a miniature linguistic system. Studies in Second Language Acquisition, v. 17, p. $379-410,1995$.

DOUGHTY, C. Cognitive underpinnings of focus on form. In: ROBINSON, P. (Ed.). Cognition and second language instruction. Cambridge: Cambridge University Press. (No prelo)

DOUGHTY, C.; WILLIAMS, J. (Ed.). Focus on form in classroom second language acquisition. Cambridge: Cambridge University Press, 1998a.

DOUGHTY, C.; WILLIAMS, J. Pedagogical choices in focus on form. In: DOUGHTY, C.; WILLIAMS, J. (Ed.). Focus on form in classroom second language acquisition. Cambridge: Cambridge University Press, 1998b. p.197261.

ELLIS, N. Rules and instances in foreign language learning: Interactions of implicit and explicit knowledge. European Journal of Cognitive Psychology, v. 5, p. 289-319, 1993.

ELLIS, R. Teaching and research: Options in grammar teaching. TESOL Quarterly, v. 32, n.1, p. 39-60, 1998.

ELLIS, R. Theoretical perspective on interaction and language learning. In: ELLIS, R. (Ed.). Learning a second language through interaction. Amsterdam: John Benjamins, 1999.

FOSTER, P. A classroom perspective on the negotiation of meaning. Applied Linguistics, v. 19, p. 1-23, 1998.

FOSTER, P.; SKEHAN, P. The influence of source of planning and focus of planning on task-based performance. Language Teaching Research, v. 3, p. 215-245, 1999.

FOTOS, S. Consciousness-raising and noticing through focus on form: grammar task performance vs. formal instruction. Applied Linguistics, v. 14, p. 385-407, 1993.

FOTOS, S. Integrating grammar instruction and communicative language use through grammar consciousness-raising tasks. TESOL Quarterly, v. 28, p. 323-51, 1994.

FOTOS, S.; ELLIS, R. Communicating about grammar: a task-based approach. TESOL Quarterly, v. 25, p. 605-628, 1991.

GASS, S. Input, interaction and the second language learner. Mahwah: Erlbaum, 1997. 
GASS, S.; VARONIS, E. Miscommunication in nonnative speaker discourse. In: COUPLAND, N., GILES, H.; WEIMANN, J. (Ed.). Miscommunication and problematic talk. Newbury Park, CA: Sage, 1991. p. 121-145.

GASS, S.; MACKEY, A.; ALVAREZ-TORRES, M. J.; FERNANDEZGARCIA, M. The effects of task repetition on linguistic output. Language Learning, v. 49, p. 549-581, 1999.

HARLEY, B. The role of focus-on-form tasks in promoting child L2 acquisition. In: DOUGHTY, C.; WILLIAMS, J. (Ed.). Focus on form in classroom second language acquisition. Cambridge: Cambridge University Press, 1998. p. 156-174.

HOLLY, F., KING, J. Vocabulary glosses in foreign language learning materials. Language Learning, v. 21, p. 213-219, 1971.

HULSTIJN, J. Retention of inferred and given word meanings: Experiments in incidental vocabulary learning. In. ARNAUD, P.; BEJOINT, H. (Ed.). Vocabulary and applied linguistics London: MacMillan, 1992 .p. 113-125.

HULSTIJN, J. When do foreign language learners look up the meaning of unfamiliar words? The influence of task and learner variables. Modern Language Journal, v. 77, p. 139-147, 1993.

HULSTIJN, J.; HOLANDER, M.; GRIEDENUS, T. Incidental vocabulary learning by advanced foreign language students: The influence of marginal glosses, dictionary use, and reoccurrence of unknown words. Modern Language Journal, v. 80, p. 327-339, 1996.

HYLAND K. Writing without conviction? Hedging in science research articles. Applied Linguistics, v. 17, p. 433-454, 1996.

IZUMI, S.; BIGELOW, M.; FUJIWARA, M.; FEARNOW, S. Testing the output hypothesis: Effects of output on noticing and second language acquisition. Studies in Second Language Acquisition, v. 21, p. 421-452, 1999

JACOBS, G. What lurks in the margin: Use of vocabulary glosses as a strategy in second language reading. Issues in Applied Linguistics, v. 5, p. 115-137, 1994.

JACOBS, G.; DUFON, P.; FONG, C. L1 and L2 glosses in L2 reading passages: Their effectiveness for increasing comprehension and vocabulary knowledge. Journal of Research in Reading, v. 17, p. 19-28, 1994.

JOURDENAIS, R.; OTA, M.; STAUFFER, S.; BOYSON, B.; DOUGHTY, C. Does textual enhancement promote noticing? A thinkaloud protocol analysis. In: SCHMIDT, R. (Ed.). Attention and awareness 
in foreign language learning. Honolulu: University of Hawai'i Press, 1995. p. 183-216.

KUPFERBERG, I.; OLSHTAIN, E. Explicit contrastive instruction facilitates the acquisition of difficult L2 forms. Language Awareness, v. 3, p. 149-165, 1996.

$\mathrm{KO}, \mathrm{M}$. Glossing in incidental and intentional learning of foreign language vocabulary and reading. University of Hawai' $i$ Working Papers in ESL, v. 13, p. 49-94, 1995.

LEOW, R. The effects of input enhancement and text length on adult readers' comprehension and intake in second language acquisition. Applied Language Learning, v. 8, p. 151-182, 1997.

LIGHTBOWN, P. The importance of timing in focus on form. In: DOUGHTY, C.; WILLIAMS, J. (Ed.). Focus on form in classroom second language acquisition. Cambridge: Cambridge University Press, 1998. p.177196.

LONG, M. H. Instructed interlanguage development. In: BEEBE, L. (Ed.). Issues in second language acquisition. New York: Newbury House, 1998. p.113-141.

LONG, M. H. Focus on form: A design feature in language teaching methodology. In: DE BOT, K., GINSBERG, R.; KRAMSCH, C. (Ed.). Foreign language research in cross-cultural perspective. Amsterdam: John Benjamins, 1991.p. 39-52.

LONG, M. H. The role of the linguistic environment in second language acquisition. In: RITCHIE, W. \& BHATIA, T. (Ed.). Handbook of research on second language acquisition. New York: Academic Press, 1996. p. 413468.

LONG, M. H.; INAGAKI, S.; ORTEGA, L. The role of implicit negative feedback in SLA: Models and recasts in Japanese and Spanish. Modern Language Journal, v. 82, p. 357-371, 1998.

LONG, M.; ROBINSON, P. Theory, research and practice. In: DOUGHTY, C.; WILLIAMS, J. (Ed.). Focus on form in classroom second language acquisition. Cambridge: Cambridge University Press, 1998. p. 15-41.

LOSCHKY, L.; BLEY-VROMAN, R. Grammar and task-based methodology. In: CROOKES, G.; GASS, S. (Ed.). Tasks and language learning, vol. 1. Clevedon, Avon: Multilingual Matters, 1993. p.123-67.

LYSTER, R. Recasts, repetition and ambiguity in L2 classroom discourse. Studies in Second Language Acquisition, v. 20, p. 51-80, 1998. 
LYSTER, R.; RANTA, L. Corrective feedback and learner uptake: Negotiation of form in communicative classrooms. Studies in Second Language Acquisition, v. 19, p. 37-66, 1997.

MACKEY, A. Input, interaction and second language development: An empirical study of question formation in ESL. Studies in Second Language Acquisition, v. 21, p. 557-587. 1999.

MACKEY, A.; PHILP, J. Recasts, interaction and interlanguage development: Are responses red herrings? Modern Language Journal, v. 82, p. 338-356, 1998.

MEHNERT, $U$. The effects of different lengths of time for planning on second language performance. Studies in Second Language Acquisition, v. 20, p. 83-108, 1998.

MURANOI, H. Focus on form through interaction enhancement: Integrating formal instruction into a communicative task in EFL classrooms. Language Learning, v. 50, n. 4, p. 617-673, 2000.

NASAJI, H.; SWAIN, M. A Vygotskian perspective on corrective feedback in L2: The effect of random vs. negotiated help on the learning of English articles. Language Awareness. (No prelo).

NOBUYOSHI, J.; ELLIS, R. Focused communication tasks and second language acquisition. ELT Journal, v. 47, p. 203-210, 1993.

OLIVER, R. Negative feedback in child NS-NNS conversation. Studies in Second Language Acquisition, v. 17, p. 459-82, 1995.

OLIVER, R. Age differences in negotiation and feedback in classroom and pairwork. Language Learning, v. 50, p. 119-151, 2000.

ORTEGA, L. Planning and focus on form in L2 oral performance. Studies in Second Language Acquisition, v. 21, p. 109-145, 1999.

OVERSTREET, M. Text enhancement and content familiarity: The focus of learner attention. Spanish Applied Linguistics, v. 2, p. 229-258, 1998. PELLETTIERI, J. Negotiation in cyberspace: The role of chatting in the development of grammatical competence. In: WARCHAUER; KERN, R. (Ed.). Network-based language teaching: Concepts and practice. Cambridge: Cambridge University Press, 2000. p. 59-86.

PICA, T. Research on negotiation: What does it reveal about second language acquisition? Language Learning, v. 44, p. 493-527, 1994.

PICA, T. Second language teaching and research relationships: A North American view. Language Teaching Research, v. 1, p. 48-72, 1997.

ROBINSON, P. Learning simple and complex second language rules under implicit, incidental, rule-search and instructed conditions. Studies in Second Language Acquisition, v. 18, p. 27-68, 1996. 
ROBINSON, P. Automaticity and generalizability of second language learning under implicit, incidental, enhanced, and instructed conditions. Studies in Second Language Acquisition, v. 19, p. 233-247, 1997.

ROSA, E.; O'NEILLl, M. Explicitness, intake and the issue of awareness: Another piece of the puzzle. Studies in Second Language Acquisition, v. 21, p. 511-553, 1999.

SCHMWT, R. The role of consciousness in second language learning. Applied Linguistics, v. 11, p. 17-46, 1990.

SCHMDT, R. Consciousness and foreign language learning. In: SCHMIDT, R. (Ed.). Attention and awareness in foreign language learning. Honolulu: University of Hawai'i Press, 1995. p. 1-63.

SEEDHOUSE, P. The case of the missing "no": The relationship between pedagogy and interaction. Language Learning, v. 47, p. 547-583, 1997.

SHEHADEH, A. Non-native speakers' production of modified comprehensible output and second language learning. Language Learning, v. 49 , p. $627-675,1999$.

SKEHAN, P. A framework for the implementation of task-based instruction. Applied Linguistics, v. 17, p. 38-62, 1996.

SKEHAN, P; FOSTER, P. The influence of task structure and processing conditions on narrative retellings. Language Learning, v. 49, p. 93-120, 1999. SPADA, N. Form-focussed instruction and second language acquisition: A review of classroom and laboratory research. Language Teaching Abstracts, v. 30, p. 73-87,1997.

SPADA, N.; LIGHTBOWN, P. Instruction and the development of questions in the L2 classroom. Studies in Second Language Acquisition, v. 15, p. 20521, 1993.

SPADA, N.; LIGHTBOWN, P. Instruction, first language influence and developmental readiness in second language acquisition. Modern Language Journal, v. 83, p. 1-22, 1999.

SWAIN, M. Three functions of output in second language learning. In: COOK, G.; SEIFLHOFER, B. (Ed.). Principle and practice in applied linguistics. Oxford: Oxford University Press, 1995. p. 125-44.

SWAIN, M. Focus on form through conscious reflection. In: DOUGHTY, C.; WILLIAMS, J. (Ed.). Focus on form in classroom second language Acquisition. Cambridge: Cambridge university Press, 1998. p. 64-81.

SWAIN , M. The output hypothesis and beyond: Mediating Acquisition through collaborative dialogue. In: LANTOLF, J. (Ed.). Sociocultural theory and second language leaming. Oxford: Oxford University Press, 2000. p. 97-114. 
SWAIN, M.; LAPKIN, S. Problems in output and the cognitive processes they generate: A step towards second language learning. Applied Linguistics, v. 16, p. 371-391, 1995.

SWAIN, M.; LAPKIN, S. Interaction and second language learning: Two adolescent French immersion students working together. Modern Language Joumal, v. 82, p. 320-337, 1998.

TAKASHIMA, H.; ELLIS, R. Output enhancement and the acquisition of past tense. In: ELLIS, R. (Ed.). Learning a second language through interaction. Amsterdam: John Benjamins, 1999. p. 173-188.

VAN DEN BRANDEN, K. Effects of negotiation on language learners' output. Language Learning, v. 47, p. 589-636, 1997.

VANPATTEN, B. Input processing and grammar instruction. New York: Ablex. 1996.

WATANABE, Y. Input, intake, and retention: Effects of increased processing on incidental learning of foreign language vocabulary. Studies in Second Language Acquisition, v. 19, p. 287-307, 1997.

WHITE, J. Getting the learners' attention: A typographical input enhancement study. In: DOUGHTY, C.; WILLIAMS, J. (Ed.). Focus on form in classroom second language Acquisition. Cambridge: Cambridge university Press, 1998. p. 85-113.

WHITE, L. Adverb placement in second language acquisition: Some positive and negative evidence in the classroom. Second Language Research, v. 7, p. 133-61, 1991.

WILLIAMS, J. Learner-generated attention to form. Language Learning, v. 49 , p. 583-625, 1999.

WILLIAMS, J.; EVANS, J. What kind of focus on which forms? In: DOUGHTY, C.; WILLIAMS, J. (Ed.). Focus on form in classroom second language Acquisition. Cambridge: Cambridge University Press, 1998. p. 139-155. 